\title{
A Comparative Study on the Risk Perceptions of the Public and Private Sectors in Public-Private Partnership (PPP) Transportation Projects in Vietnam
}

\author{
Veerasak Likhitruangsilp ${ }^{1}$, Sy Tien Do ${ }^{1,2, *}$, and Masamitsu Onishi ${ }^{3}$ \\ 1 Department of Civil Engineering, Faculty of Engineering, Chulalongkorn University, Bangkok, Thailand \\ 2 Faculty of Civil Engineering, Ho Chi Minh City University of Technology, Ho Chi Minh, Vietnam \\ 3 Department of Planning and Management Systems, Kyoto University, Kyoto, Japan \\ *E-mail: sy.dotien@hcmut.edu.vn (Corresponding author)
}

\begin{abstract}
Large transportation projects such as highways are expensive, complex, and dynamic in nature. Acquiring large investment capitals for these projects is always a major challenge for every nation. To solve this problem, Vietnamese government has called for the participation of private entities in the form of publicprivate partnership (PPP). Attracting private investors is a vital and challenging step for implementing PPP transportation projects in Vietnam. This paper examines the similarities and differences of risk perceptions of the public and private sectors for the investment of PPP transportation projects in Vietnam. Questionnaire surveys are used to collect data for assessing the likelihoods of occurrence and impacts of risk factors from 123 experienced professionals from both public and private entities. We found that the two most critical risk factors (CRFs) are land acquisition and compensation, and delay in project approvals and permits. The results from an independent sample t-test indicate the different risk perceptions of the public and private sectors for eight CRFs: (1) corruption, (2) change of project scope, (3) lack of transparency in bidding, (4) inflation, (5) payment issues, (6) inadequate feasibility study, (7) inappropriate allocation of responsibility and risk, and (8) fluctuation of interest rate. These eight CRFs are categorized into three major groups: the tendering process, commercial problems, and payment issues. These results can be used for establishing appropriate public policies to promote private investments in PPP transportation projects. Meanwhile, private investors would also have a better understanding of PPP transportation project development in Vietnam.
\end{abstract}

Keywords: Critical risk factor (CRF), public-private partnership (PPP), risk perceptions, risk management, transportation projects, Vietnam.

ENGINEERING JOURNAL Volume 21 Issue 7

Received 28 March 2017

Accepted 31 May 2017

Published 29 December 2017

Online at http://www.engj.org/

DOI:10.4186/ej.2017.21.7.213 


\section{Introduction}

Since Vietnam has become a member of the World Trade Organization (WTO) in 2006, international capital investments have been increasing enormously, especially in the construction sector. This plays a vital role in the nation's economic development. In parallel with the rapid economic growth, the demand for infrastructures has also been escalating in recent years. These infrastructure projects are typically financed by state budgets, government bonds, and official development assistances (ODAs). However, in present the state budgets are quite limited because national and state-owned enterprise debt loads are closely controlled. Attracting investment through government bonds is also considered ineffective due to their low rates of return and illiquidity. Since Vietnam is not an underdeveloped country anymore, the ODA funds have been minimal. Alternatively, the Vietnamese government has called for the participation by private entities such as domestic and foreign companies, and international joint venture companies. Another financing alternative is that government agencies cooperate with private investors in a business form called public-private partnership or PPP.

Since 1993, various forms of PPP have been implemented in transportation infrastructure projects in Vietnam such as Build-Operate-Transfer (BOT), Build-Transfer (BT), Build-Transfer-Operate (BTO), pilot PPP (in 2010), and PPP (in 2015). Legislations regarding BOT, BT, and BTO (BOT/BT/BTO) projects were issued at the end of 2009 [1] and revised in early 2011. The government also introduced pilot PPP regulations [2] for a number of projects. These pilot regulations functioned as a basis for further improving mechanisms, policies, and regulations on the investment in the PPP form. As an effort to bridge the potential funding gap, the government turned to the pilot PPP form. While the existing BOT legislation is designed primarily for private investors, pilot PPP projects are designed to pool capitals of the public and private sectors. These investment capitals include state participation, which can be a portion of project funding and non-financial supports. The pilot PPP framework aims to attract non-governmental investment in a wide variety of public projects and create a framework for the government's support where a funding viability gap exists. This PPP framework also facilitates the implementation of feasibility studies that form a basis for determining the amount and form of the government's support and a risk-sharing mechanism among the involved parties prior to the selection of project investors. The pilot PPP scheme is implemented in parallel with the existing BOT legislation. The legal framework for the pilot PPP program is expected to form a basis for a more comprehensive PPP model [3]. Since then, more than 20 pilot public service and infrastructure PPP projects have adopted this scheme. Unfortunately, many projects have been stalled, such as Dau Giay - Phan Thiet Expressway - the first pilot PPP transportation project in Vietnam. Although the Vietnamese government committed the equality competitive level for this project by adopting the open bidding procedure, there was no tender. The prime minister approved the Bitexco Group as the first investor from 2007. Since then there has been no succeeding investor. The performance of pilot PPP transportation projects in Vietnam must encounter various problems such as lack of transparency in the business environment, inadequate legal frameworks, complex procurement procedures, and land acquisition.

The latest regulations concerning PPP were introduced in 2015. Both public and private sectors are still not familiar with these new regulations [4]. The public sector has limited experience in this new PPP scheme, whereas it is not attractive for the private sector, which concerns about its risky investment environment. Although the Vietnamese government has issued various supporting and incentive policies to attract private investors, their interest was still dreadfully low due to a lack of appropriate incentive policies and transparent legal frameworks.

Due to all reasons above, it is vital to comprehend both public and private sectors' risk perceptions so that the Vietnamese government can establish appropriate policies and frameworks that make PPP transportation projects attractive for both parties, especially private investors. Unfortunately, the number of research works on PPP transportation projects in Vietnam is considerably low. This paper focuses on identifying, assessing, and ranking the critical risks affecting the performance of previous BOT/BT/BTO and pilot PPP transportation projects as well as examining different risk perceptions between the public and private sectors. The results will be useful for both domestic and foreign participants in PPP transportation projects in Vietnam.

\section{Previous Research}

A number of research works have investigated various aspects of PPP. Herein, we primarily focus on risks associated with PPP implementation and their impacts on the performance of project participants. Analyzing 
risks associated with PPP project development can be divided into two major stages: (1) project investment (e.g., expanding existing networks, constructing new facilities, or renovating existing facilities) and (2) operation and maintenance services. To manage PPP risks efficiently, it is necessary to identify and categorize risk factors. The risks of PPP projects can be divided into two main groups: the systematic risk group and the unsystematic risk group [5]. The systematic risk group entails risks that are beyond the control of project participants such as political, legal, economic, and environmental risks. The unsystematic risk group includes risks related to the project itself such as construction, design, operation, finance, and revenue risks. Critical risks encountered in the operation phase of a Bangkok expressway, a PPP project in Thailand, was investigated [6]. In this project, the major participants in the sponsoring consortium had left the project due to disputes with the granting authority regarding user fees. In addition, the government's delay on increasing toll fee and poor revenue directly caused cash-flow problems, which contributed to rescheduling debt repayment. In another study, risk factors were grouped into two main categories: the general risk and the project-specific risk [7]. The general risk was subdivided into political, commercial, and legal risks. Meanwhile, the project-specific risk, which can be controlled by stakeholders, was identified and analyzed in accordance with life-cycle of PPP projects: the development phase, the construction phase, and the operation phase. It was concluded that the private sector in Vietnam viewed BOT projects riskier than the public sector did. For foreign investors, nine out of ten most critical risks were in the general risk group. As a result, the BOT infrastructure projects in Vietnam were not quite attractive for foreign investors.

Twenty-two risks in Indian BOT road projects were identified throughout their life-cycle [8]. Eight risks were listed as very critical. Among them, traffic revenue and delay in land acquisition were the most critical risks. Other 17 risk factors were recognized during the development phase of Indian PPP projects [9]. Risks related to cost overrun, delay, and financial closures have been reported to be the most critical.

For PPP construction projects in China, seventeen critical risk factors were identified, which were classified into six groups: (1) macroeconomic, (2) construction and operation, (3) government maturity, (4) market environment, (5) economic viability, and (6) government intervention [10]. Among them, the most critical risks were government intervention, poor public decision-making process, government corruption, financing risk, inadequate law, and supervision system. These results were consistent with those of [11], which revealed that the intervention by the government and a poor public decision-making process were a major threat on the success of PPP highway projects in China. Twenty-three critical risk factors were also found that affect the performance of PPP projects in Singapore such as lack of support by the government, financial availability, construction delay, inadequate experience in PPP, and unstable government [12]. Although Singapore has experienced a long period of political stability, government-related issues (e.g., support and stability) were considered the most concerned issues by respondents. Financial capacity and the private sector's experience on PPP were imperative harms to the performance of PPP projects.

\section{Research Methodology}

Figure 1 illustrates the research methodology adopted in this paper, which can be broken down into five steps.

Step 1 - Compile the risk factors in PPP projects. The risk factors affecting the performance of PPP projects are first compiled through comprehensive literature review. These risk factors are then verified by a group of professionals experienced in PPP projects.

Step 2 - Conduct a pilot interview and a questionnaire survey. A set of questionnaire survey is prepared based on the relevant literature and current PPP practices in Vietnam. A pilot interview and questionnaire survey are conducted to gather necessary information on the risk factors perceived by a group of PPP transportation project professionals. The questionnaire survey encompasses several issues regarding the investment in PPP transportation projects in Vietnam; nonetheless, this paper presents only the project risk factors. The preliminary questionnaire is tested to justify its relevancy. The comments and feedbacks of experienced professionals are used to finalize the questionnaire.

Step 3-Conduct a large-scale questionnaire survey. The revised questionnaire is then distributed to other experienced professionals in PPP transportation projects in Vietnam in a large-scale survey. To elicit the probability and impact of each risk factor, the respondents are asked to specify the probability (rating 1 to 5) and impact (rating A to E) of each risk factor, based on the five-point Likert scale. The respondents' opinions are converted into numerical scales (from 0 to 1 ) and analyzed. 
Step 4 - Perform risk assessment. In this paper, the risk level of each risk factor is assessed by the probabilityimpact method [13]. The combined risk level (RL) of a certain risk factor can be calculated by using the following formula:

$$
R L=P+I-P \times I
$$

where $\quad R L=$ combined risk level (on a scale of 0 to 1 )

$P=$ probability of risk (measured on a scale of 0 to 1 )

$I=$ risk impact (measured on a scale of 0 to 1 )

All the risks are then classified into three levels: high, medium, and low. Per the results from the pilot interview, the boundaries between the high- and the medium-risk levels, and between the medium- and the low-risk levels are defined at $R L=0.80$ and $R L=0.45$, respectively [14], as shown in Fig. 2 .

To statistically examine the similarity and difference of the perceptions between the public and private sectors, an independent sample $t$-test is performed. Finally, risk responsive strategies are suggested by the respondents from the private sector.

Step 5 - Validate the results. A group of PPP experts from the government and the private sector is invited to validate the results.

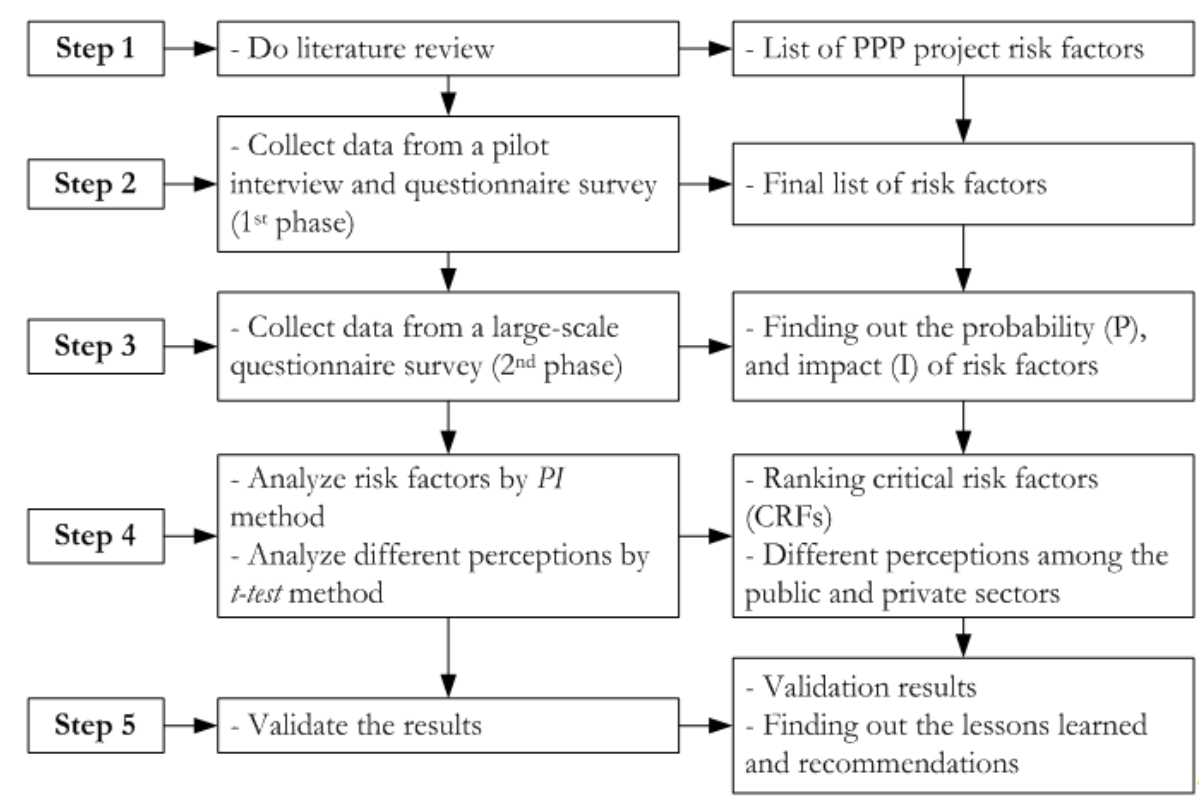

Fig. 1. Research methodology. 


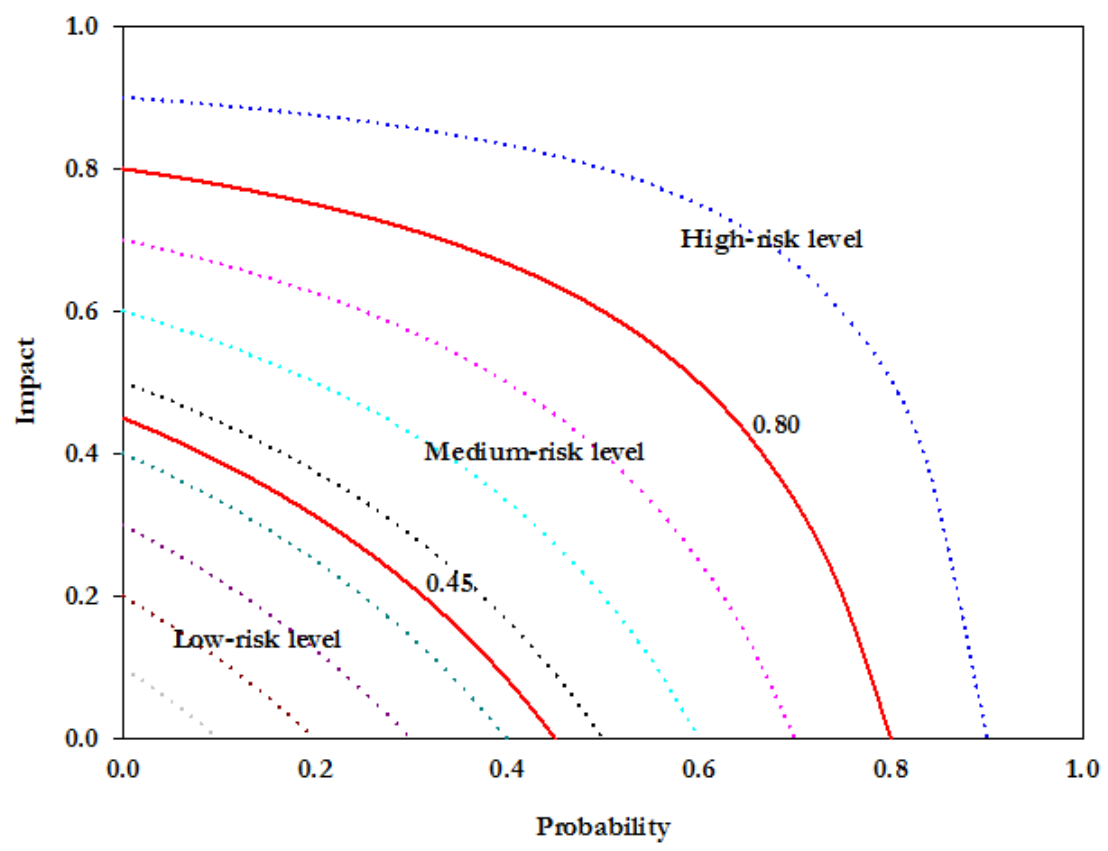

Fig. 2. Risk contour diagram of low-, medium-, and high-risk levels.

\section{Research Data Collection}

To identify the risk factors in PPP transportation projects in Vietnam, risk factors in general construction projects presented in past research works are first examined and similar risk factors are compiled, as shown in Table 1. Since this research focuses on PPP transportation projects, the compiled risk factors are reviewed by seven experienced professionals in PPP transportation projects through in-depth interviews and verified with case studies. The professionals that participate in this pilot survey entail two officers from the Ministry of Planning and Investment, a PPP investor, a consultant, a contractor, and two university lecturers. Table 2 provides their profiles. As can be seen, all of them have at least ten years of experience in PPP transportation projects in Vietnam. Each participant is provided with a list of risk factors and is asked to specify the risk factors that affect the performance of PPP transportation projects. According to their opinions, eight risk factors are removed, and three new risk factors are added to the list. Thus, 33 risk factors are affirmed by this group of professionals. In-depth interviews with these experts are then carried out to compile additional data from ten previous PPP transportation projects in Vietnam, as shown in Table 3. As can be seen, three new factors are added to the list, namely, unclear about state participant potion (D5), breach of contract by government (D7), and inadequate feasibility study (D8). A total of 33 risk factors that were encountered in these past projects are listed in Table 3.

The next step is conducting a large-scale data survey. A questionnaire is prepared based on the risk factors previously identified. It is distributed to another group of professionals that is also experienced in PPP transportation projects in Vietnam, which can be categorized into the public sector and the private sector. The public sector entails the officers in relevant government agencies, whereas the private sector includes investors, consultants, contractors, financiers, and designers, who have experienced PPP projects. A total of 320 questionnaires are distributed in Vietnam, and 123 valid responses are (38.4\% response rate). The response rates for the public and private sectors are $20.3 \%$ and $79.7 \%$, respectively, as shown in Table 4 .

The respondents are line directors or project managers $(57.7 \%)$, directors or deputy directors $(23.6 \%)$, and project managers (34.1\%). The work experiences of the respondents are less than 10 years $(43.1 \%)$ and 10 years and more $(56.9 \%)$. More than $99 \%$ of respondents have experience in one or more PPP projects. Clearly, these survey results can represent the opinion of a majority of PPP experts in Vietnam.

Finally, to confirm the accuracy of the final results, three PPP experts, one from the government, and two from the private sector, are invited to participate in the validation process via interviews (see Table 2). 
Table 1. Risk factors compiled from past research works.

\begin{tabular}{|c|c|c|c|c|c|c|c|c|c|c|c|}
\hline \multirow{2}{*}{ No. } & \multirow{2}{*}{ Risk factors } & \multicolumn{10}{|c|}{ Literature } \\
\hline & & A & $\mathrm{B}$ & $\mathrm{C}$ & $\mathrm{D}$ & $\mathrm{E}$ & $\mathrm{F}$ & G & $\mathrm{H}$ & $\mathrm{I}$ & $\mathrm{J}$ \\
\hline 1 & Government's intervention & & & & $\checkmark$ & & & $\checkmark$ & $\checkmark$ & & $\sqrt{ }$ \\
\hline 2 & Delay in project approvals and permits & & & & $\checkmark$ & $\checkmark$ & $\checkmark$ & $\checkmark$ & & $\checkmark$ & $\checkmark$ \\
\hline 3 & Corruption & & & & & $\checkmark$ & & $\checkmark$ & $\checkmark$ & $\checkmark$ & $\checkmark$ \\
\hline 4 & Expropriation and nationalization $(*)$ & & & & $\checkmark$ & $\checkmark$ & & $\checkmark$ & $\checkmark$ & & \\
\hline 5 & Political instability $(*)$ & & & $\checkmark$ & & & & & & & \\
\hline 6 & Inadequate law and supervision system & & & & & $\checkmark$ & $\checkmark$ & & & $\checkmark$ & $\checkmark$ \\
\hline 7 & Change in laws and regulations & & & & $\checkmark$ & & $\checkmark$ & $\checkmark$ & $\checkmark$ & $\checkmark$ & $\checkmark$ \\
\hline 8 & Change in tax regulation & & & & $\checkmark$ & $\checkmark$ & & $\checkmark$ & $\checkmark$ & $\checkmark$ & $\checkmark$ \\
\hline 9 & Financial market & & $\checkmark$ & & & & $\checkmark$ & & $\checkmark$ & $\checkmark$ & \\
\hline 10 & Fluctuation of interest rate & & & & $\checkmark$ & $\checkmark$ & & $\checkmark$ & $\checkmark$ & $\checkmark$ & $\checkmark$ \\
\hline 11 & Foreign exchange fluctuations & & & & $\checkmark$ & $\checkmark$ & & $\checkmark$ & $\checkmark$ & & $\checkmark$ \\
\hline 12 & Inflation & & & & $\checkmark$ & $\checkmark$ & & $\checkmark$ & $\checkmark$ & $\checkmark$ & $\checkmark$ \\
\hline 13 & Price change $(*)$ & & & & $\checkmark$ & $\checkmark$ & & & & & \\
\hline 14 & Insufficient financial audit $(*)$ & & & & & & & & $\checkmark$ & & \\
\hline 15 & Poor public decision-making process & & & & $\checkmark$ & $\checkmark$ & & & $\checkmark$ & & $\checkmark$ \\
\hline 16 & Lack of transparency in bidding & & & & & & & & $\checkmark$ & & \\
\hline 17 & Subjective project evaluation method & & & & & $\checkmark$ & & & $\checkmark$ & & $\checkmark$ \\
\hline 18 & Supporting incentive of government & & & & & & & & & $\checkmark$ & \\
\hline 19 & Conflicting or imperfect contract & & & & & $\checkmark$ & & $\checkmark$ & $\checkmark$ & $\checkmark$ & \\
\hline 20 & Unfair process of selection of private sector & & & & & $\checkmark$ & & & & & \\
\hline 21 & $\begin{array}{l}\text { Inappropriate allocation of responsibility and } \\
\text { risk }\end{array}$ & & & & & & & $\checkmark$ & $\checkmark$ & $\checkmark$ & \\
\hline 22 & Low capacity of SPV & & & & & & $\checkmark$ & & & & \\
\hline 23 & Change of project scope & & & & & & $\checkmark$ & & & $\checkmark$ & \\
\hline 24 & Land acquisition and compensation & & $\checkmark$ & & $\checkmark$ & & $\checkmark$ & $\checkmark$ & $\checkmark$ & & $\checkmark$ \\
\hline 25 & Problems due to partner's different practice & & & & $\checkmark$ & & $\checkmark$ & $\checkmark$ & & $\checkmark$ & $\checkmark$ \\
\hline 26 & Lack of supporting infrastructure & & & & & $\checkmark$ & & $\checkmark$ & $\checkmark$ & & $\checkmark$ \\
\hline 27 & Environmental protection risk & & & & & & $\checkmark$ & & $\checkmark$ & $\checkmark$ & \\
\hline 28 & Force majeure risk & & & & $\checkmark$ & $\checkmark$ & $\checkmark$ & $\checkmark$ & $\checkmark$ & $\checkmark$ & $\checkmark$ \\
\hline 29 & Material/labor non-availability $(*)$ & & & & & $\checkmark$ & & & & & \\
\hline 30 & Completion issues & & $\checkmark$ & & & $\checkmark$ & $\checkmark$ & $\checkmark$ & $\checkmark$ & $\checkmark$ & $\checkmark$ \\
\hline 31 & $\begin{array}{l}\text { Early termination of concession by } \\
\text { concession company }\end{array}$ & & & & $\checkmark$ & $\checkmark$ & & & & & $\checkmark$ \\
\hline 32 & Toll fee issues & & $\checkmark$ & & & & & & & & \\
\hline 33 & Payment issues & & & & & $\checkmark$ & & $\checkmark$ & $\checkmark$ & & \\
\hline 34 & Demand issues & $\checkmark$ & $\checkmark$ & & & $\checkmark$ & & & & $\checkmark$ & $\checkmark$ \\
\hline 35 & Operator inability & $\checkmark$ & & & & & & & & $\checkmark$ & \\
\hline 36 & $\begin{array}{l}\text { Residual assets risk (after concession period) } \\
(*)\end{array}$ & & & & $\checkmark$ & $\checkmark$ & & $\checkmark$ & & & \\
\hline 37 & Cost escalation risks $(*)$ & $\checkmark$ & & & & & & & & & \\
\hline 38 & Supply risk $(*)$ & $\checkmark$ & & & & & & & & & \\
\hline
\end{tabular}

Reference: $\mathrm{A}=[15] ; \mathrm{B}=[8] ; \mathrm{C}[16] ; \mathrm{D}=[7] ; \mathrm{E}=[10] ; \mathrm{F}=[9] ; \mathrm{G}=[17] ; \mathrm{H}=[11] ; \mathrm{I}=[12] ;$ and $\mathrm{J}=$ [18].

(*) Risk factors that are removed 
Table 2. Profiles of the participants in the pilot study.

\begin{tabular}{lllll}
\hline No. & Designation & Organization & Experience & Sector \\
\hline 1 & Public procurement policy & Ministry of Planning and Investment & $\geq 10$ years & Public \\
2 & Assistant director & Ministry of Planning and Investment $\left(^{*}\right)$ & $\geq 10$ years & Public \\
3 & Representative investors & PPP investor $\left(^{*}\right)$ & $\geq 10$ years & Private \\
4 & Assistant director & Consultant & $\geq 10$ years & Private \\
5 & Project management & Contractor & $\geq 10$ years & Private \\
6 & Expert & University $(*)$ & $\geq 10$ years & Private \\
7 & Project management & University & $\geq 10$ years & Private \\
\hline
\end{tabular}

(*) Experienced professionals that also validate the final results

\section{Results and Discussion}

\subsection{Risk Identification}

By reviewing various past research working, interviewing PPP professionals, and examining PPP case studies in Vietnam, 33 risk factors are identified, as shown in Table 3. The hierarchical risk breakdown structure (HRBS) is used to specify risk groups, risk categories, and risk factors. A risk code system is established to manage all the risk factors. As shown in Fig. 3, the risk factors are divided into two main groups:

1) General risks, which include the risk factors associated with the PPP project's environment. This risk group is subdivided into the political, legal, and commercial risk categories.

2) Project-specific risks, which encompass the risk factors related to the PPP project's performance throughout its life-cycle. This risk group is divided further into the design and procurement, construction, and operation categories.

\subsection{Critical Risk Factors}

To investigate the effect of risk on the performance of PPP transportation projects in Vietnam, the concept of combined risk level (RL) is adopted to rank all the risk factors. Figure 4 displays a contour diagram, which displays the probabilities $(P)$ and impacts $(I)$ of all 33 risk factors. As can be seen, this contour diagram is divided into three zones, namely, the low-risk level (no risk factor), the medium-risk level (10 risk factors), and the high-risk level (23 risk factors). Table 5 illustrates the means and the ranks of 23 critical risk factors (CRFs) $(R L \geq 0.8)$ based on the opinions of the public sector, the private sector, and both sectors. Tables 6 and 7 display the ranking of the probabilities $(P)$ and impacts $(I)$ of the six risk categories based on the opinions of the public sector, the private sector, and both sectors, respectively. 
Table 3. Principal risk factors prevailed in past PPP transportation projects in Vietnam.

\begin{tabular}{|c|c|c|c|c|c|c|c|c|c|c|c|c|c|}
\hline \multirow{2}{*}{\multicolumn{2}{|c|}{ Categories }} & \multirow{2}{*}{ ID } & \multirow{2}{*}{ Risk factors } & \multicolumn{10}{|c|}{ Case No. } \\
\hline & & & & 1 & 2 & 3 & 4 & 5 & 6 & 7 & 8 & 9 & 10 \\
\hline \multirow{10}{*}{ 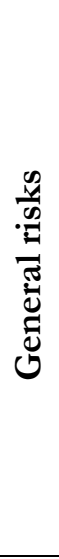 } & & P1 & Government's intervention & & & $\checkmark$ & $\checkmark$ & & & & & & \\
\hline & $:$ & P2 & $\begin{array}{l}\text { Delay in project approvals and } \\
\text { permits }\end{array}$ & & & $\checkmark$ & $\checkmark$ & & & $\checkmark$ & & & \\
\hline & & P3 & Corruption & & & & & $\checkmark$ & & & & & \\
\hline & శ్ & L1 & $\begin{array}{l}\text { Inadequate law and supervision } \\
\text { system }\end{array}$ & & & $\checkmark$ & & & & & & & \\
\hline & $\stackrel{\omega}{\oplus}$ & $\mathrm{L} 2$ & Change in laws and regulations & & & & & & & & & & $\checkmark$ \\
\hline & & L3 & Change in tax regulation & $\checkmark$ & $\checkmark$ & $\checkmark$ & $\checkmark$ & $\checkmark$ & $\checkmark$ & $\checkmark$ & $\checkmark$ & $\checkmark$ & $\checkmark$ \\
\hline & $\overline{\frac{\pi}{2}}$ & C1 & Financial market & & & & $\checkmark$ & & & & & & \\
\hline & 过 & C2 & Fluctuation of interest rate & & $\checkmark$ & & & & & & & & \\
\hline & घี & C3 & Foreign exchange fluctuations & & & & $\checkmark$ & & & & & & \\
\hline & j & $\mathrm{C} 4$ & Inflation & & $\checkmark$ & & $\checkmark$ & & & & & & \\
\hline \multirow{23}{*}{ 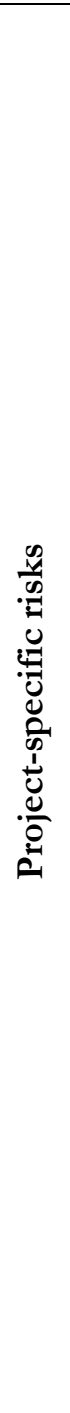 } & \multirow{11}{*}{ 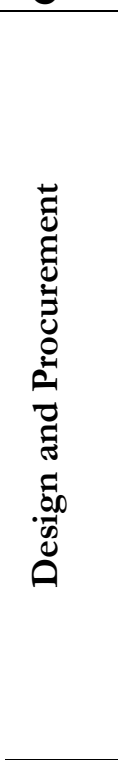 } & D1 & Poor decision-making process & & & $\checkmark$ & & & & & & $\checkmark$ & \\
\hline & & D2 & Lack of transparency in bidding & & & $\checkmark$ & $\checkmark$ & & & & & $\checkmark$ & \\
\hline & & D3 & $\begin{array}{l}\text { Subjective project evaluation } \\
\text { method }\end{array}$ & $\checkmark$ & $\checkmark$ & $\checkmark$ & $\checkmark$ & & & & & $\checkmark$ & \\
\hline & & $\mathrm{D} 4$ & $\begin{array}{l}\text { Supporting incentive of } \\
\text { government }\end{array}$ & & & & $\checkmark$ & & & & & & \\
\hline & & D5 & $\begin{array}{l}\text { Unclear about state participant } \\
\text { portion }(*)\end{array}$ & $\checkmark$ & $\checkmark$ & $\checkmark$ & $\checkmark$ & $\checkmark$ & $\checkmark$ & $\checkmark$ & $\checkmark$ & $\checkmark$ & $\checkmark$ \\
\hline & & D6 & Conflicting or imperfect contract & & & & $\checkmark$ & $\checkmark$ & & & & $\checkmark$ & \\
\hline & & D7 & $\begin{array}{l}\text { Breach of contract by } \\
\text { Government }\left(^{*}\right)\end{array}$ & $\checkmark$ & & & $\checkmark$ & & & & $\checkmark$ & & \\
\hline & & D8 & Inadequate feasibility study $(*)$ & $\checkmark$ & $\checkmark$ & $\checkmark$ & $\checkmark$ & $\checkmark$ & $\checkmark$ & $\checkmark$ & & $\checkmark$ & \\
\hline & & D9 & $\begin{array}{l}\text { Unfair process of selection of } \\
\text { private sector }\end{array}$ & & & & & & & & & $\checkmark$ & \\
\hline & & D10 & $\begin{array}{l}\text { Inappropriate allocation of } \\
\text { responsibility and risk }\end{array}$ & $\checkmark$ & $\checkmark$ & $\checkmark$ & $\checkmark$ & & $\checkmark$ & & & & \\
\hline & & D11 & Low capacity of SPV & & $\checkmark$ & & $\checkmark$ & $\checkmark$ & $\checkmark$ & $\checkmark$ & & $\checkmark$ & \\
\hline & \multirow{6}{*}{ 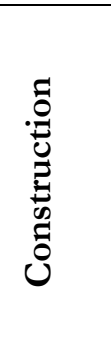 } & Co1 & Change of project scope & $\checkmark$ & & & & $\checkmark$ & & & $\checkmark$ & $\checkmark$ & $\checkmark$ \\
\hline & & $\mathrm{Co} 2$ & $\begin{array}{l}\text { Land acquisition and } \\
\text { compensation }\end{array}$ & $\checkmark$ & $\checkmark$ & $\checkmark$ & & $\checkmark$ & & $\checkmark$ & $\checkmark$ & & \\
\hline & & Co3 & $\begin{array}{l}\text { Problems due to partner's } \\
\text { different practice }\end{array}$ & & & & & & & & & $\checkmark$ & \\
\hline & & $\mathrm{Co} 4$ & Lack of supporting infrastructure & $\checkmark$ & & $\checkmark$ & $\checkmark$ & & & & $\checkmark$ & & \\
\hline & & Co5 & Environmental protection risk & & & & & & & & & & \\
\hline & & Co6 & Force majeure risk & $\checkmark$ & $\checkmark$ & & $\checkmark$ & & & & & & \\
\hline & \multirow{6}{*}{ 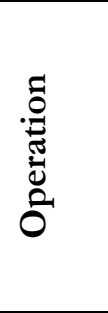 } & O1 & Completion issues & $\checkmark$ & $\checkmark$ & $\checkmark$ & $\checkmark$ & $\checkmark$ & $\checkmark$ & $\checkmark$ & & & \\
\hline & & $\mathrm{O} 2$ & $\begin{array}{l}\text { Early termination of concession by } \\
\text { concession company }\end{array}$ & $\checkmark$ & $\checkmark$ & $\checkmark$ & $\checkmark$ & & $\checkmark$ & $\checkmark$ & & & \\
\hline & & $\mathrm{O} 3$ & Toll fee issues & & $\checkmark$ & & $\checkmark$ & & $\checkmark$ & & & & \\
\hline & & $\mathrm{O} 4$ & Payment issues & & & & & $\checkmark$ & $\checkmark$ & $\checkmark$ & $\checkmark$ & & \\
\hline & & $\mathrm{O} 5$ & Demand & & $\checkmark$ & $\checkmark$ & $\checkmark$ & & & & & & \\
\hline & & $\mathrm{O} 6$ & Operator inability & & & & & & & & & & $\checkmark$ \\
\hline \multicolumn{14}{|c|}{$\begin{array}{l}\text { Case 1: Binh Trieu II Road Bridge; Case 2: Yen Lenh Bridge; Case 3: Ong Thin Bridge; Case 4: Phu My } \\
\text { Bridge; Case 5: BOT 1A National Highway, An Suong - An Lac; Case 6: } 13 \text { National Highway, HCM- } \\
\text { Binh Duong; Case 7: 1K National Highway, HCM-Bien Hoa; Case 8: BOT My Phuoc-Tan Van } \\
\text { Highway; Case 9: Deo Ca Tunnel; Case 10: Co May Bridge }\end{array}$} \\
\hline
\end{tabular}


Table 4. Questionnaire return rate.

\begin{tabular}{|c|c|c|c|c|c|c|}
\hline Stakeholder & $\begin{array}{l}\text { Questionnaire } \\
\text { distributed }\end{array}$ & $\begin{array}{c}\text { Response } \\
\text { received }\end{array}$ & $\begin{array}{c}\text { Response } \\
\text { rate }\end{array}$ & $\begin{array}{c}\text { Proportion } \\
(\%)\end{array}$ & Partner & Number \\
\hline $\begin{array}{l}\text { Government } \\
\text { Agencies }\end{array}$ & 43 & 25 & $58.1 \%$ & $20.3 \%$ & $\begin{array}{l}\text { Private } \\
\text { sector* }\end{array}$ & 98 \\
\hline Private Investors & 132 & 55 & $41.7 \%$ & $44.7 \%$ & $\begin{array}{l}\text { Public } \\
\text { sector** }\end{array}$ & 25 \\
\hline Consultants & 61 & 27 & $44.3 \%$ & $22.0 \%$ & Total & 123 \\
\hline Contractors & 53 & 10 & $18.9 \%$ & $8.1 \%$ & & \\
\hline Financiers & 20 & 5 & $25.0 \%$ & $4.1 \%$ & & \\
\hline Designers & 11 & 1 & $9.1 \%$ & $0.8 \%$ & & \\
\hline Total & 320 & 123 & $38.4 \%$ & $100.0 \%$ & & \\
\hline
\end{tabular}

*The private sector includes private investors, consultants, contractors, financiers, and designers.

**The public sector includes the officers in relevant government departments.

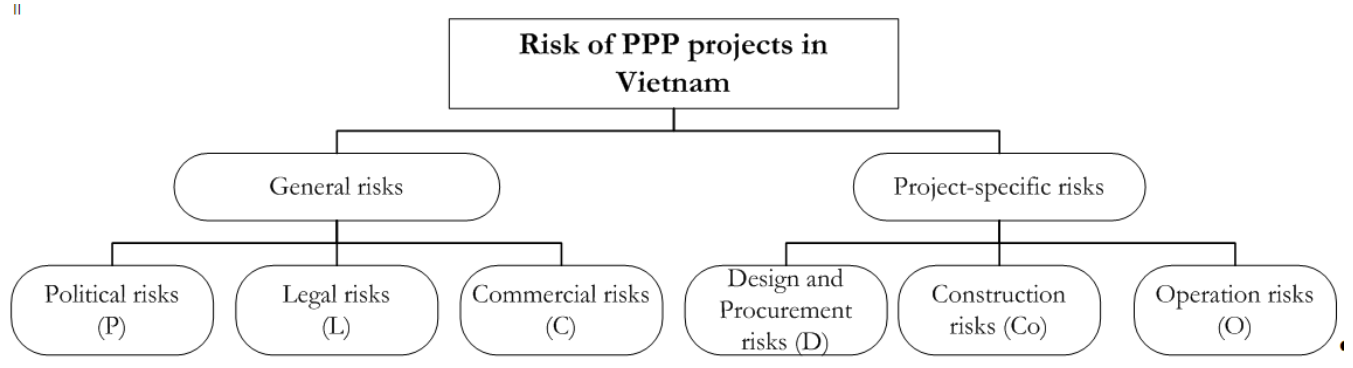

Fig. 3. Hierarchical risk breakdown structure (HRBS) of PPP transportation projects.

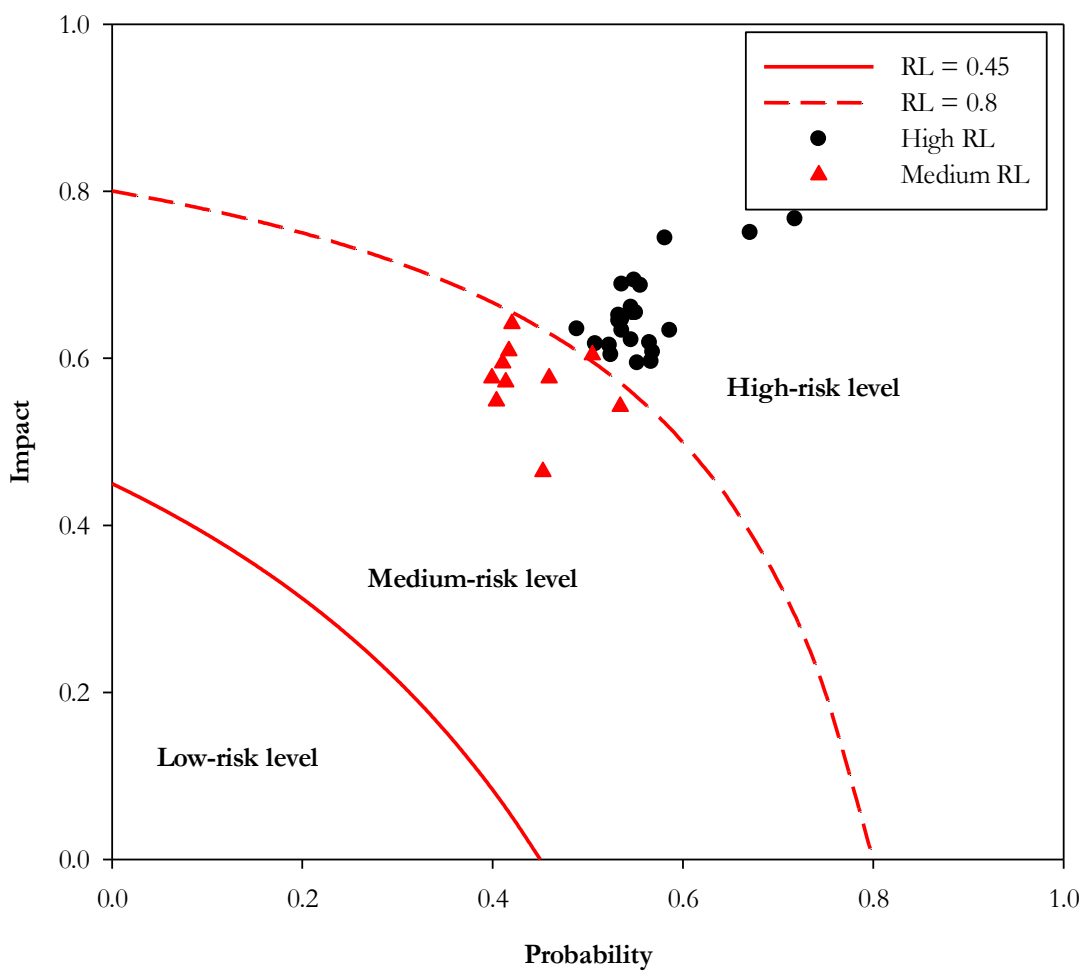

Fig. 4. Contour diagram containing 33 risk factors. 
Table 5. Risk perceptions of the public and private sectors in PPP transportation projects.

\begin{tabular}{|c|c|c|c|c|c|c|c|}
\hline \multirow{2}{*}{ ID } & \multirow{2}{*}{ Critical risk factor (CRF) } & \multicolumn{2}{|c|}{ Overall } & \multicolumn{2}{|c|}{ Public sector } & \multicolumn{2}{|c|}{ Private sector } \\
\hline & & Mean & Rank & Mean & Rank & Mean & Rank \\
\hline $\mathrm{Co} 2$ & Land acquisition and compensation & 0.924 & 1 & 0.904 & 1 & 0.929 & 1 \\
\hline $\mathrm{P} 2$ & Delay in project approvals and permits & 0.912 & 2 & 0.886 & 2 & 0.919 & 2 \\
\hline D8 & Inadequate feasibility study & 0.878 & 3 & 0.830 & 7 & 0.891 & 3 \\
\hline $\mathrm{C} 1$ & Financial market & 0.852 & 4 & 0.838 & 5 & 0.856 & 6 \\
\hline D3 & Subjective project evaluation method & 0.851 & 5 & 0.840 & 3 & 0.854 & 7 \\
\hline $\mathrm{L} 2$ & Change in laws and regulations & 0.847 & 6 & 0.839 & 4 & 0.849 & 8 \\
\hline $\mathrm{C} 2$ & Fluctuation of interest rate & 0.837 & 7 & 0.799 & 11 & 0.846 & 9 \\
\hline P3 & Corruption & 0.835 & 8 & 0.698 & 27 & 0.868 & 4 \\
\hline Co1 & Change of project scope & 0.834 & 9 & 0.736 & 22 & 0.859 & 5 \\
\hline D4 & Supporting incentive of government & 0.829 & 10 & 0.803 & 9 & 0.837 & 11 \\
\hline D1 & Poor decision-making process & 0.829 & 11 & 0.801 & 10 & 0.836 & 12 \\
\hline D10 & $\begin{array}{l}\text { Inappropriate allocation of responsibility and } \\
\text { risk }\end{array}$ & 0.829 & 12 & 0.787 & 13 & 0.840 & 10 \\
\hline O5 & Demand & 0.828 & 13 & 0.829 & 8 & 0.827 & 17 \\
\hline L1 & Inadequate law and supervision system & 0.823 & 14 & 0.790 & 12 & 0.831 & 13 \\
\hline $\mathrm{Co} 4$ & Lack of supporting infrastructure & 0.813 & 15 & 0.766 & 18 & 0.824 & 18 \\
\hline O1 & Completion issues & 0.812 & 16 & 0.780 & 15 & 0.820 & 19 \\
\hline O4 & Payment issues & 0.811 & 17 & 0.739 & 20 & 0.829 & 15 \\
\hline D2 & Lack of transparency in bidding & 0.811 & 18 & 0.727 & 25 & 0.831 & 14 \\
\hline $\mathrm{C} 4$ & Inflation & 0.809 & 19 & 0.727 & 24 & 0.829 & 16 \\
\hline O3 & Toll fee issues & 0.808 & 20 & 0.773 & 16 & 0.818 & 20 \\
\hline D9 & Unfair process of selection of private sector & 0.804 & 21 & 0.753 & 19 & 0.816 & 21 \\
\hline D6 & Conflicting or imperfect contract & 0.802 & 22 & 0.785 & 14 & 0.807 & 22 \\
\hline D11 & Low capacity of SPV & 0.801 & 23 & 0.838 & 6 & 0.792 & 24 \\
\hline
\end{tabular}

Table 6. Ranking of the probabilities $(P)$ of the six risk categories.

\begin{tabular}{lcccccccc}
\hline \multirow{2}{*}{ Risk categories } & \multicolumn{2}{c}{ Overall } & & \multicolumn{2}{c}{ Public sector } & & \multicolumn{2}{c}{ Private sector } \\
\cline { 2 - 3 } & Mean & Rank & & Mean & Rank & & Mean & Rank \\
\hline Political & 0.558 & 1 & & 0.442 & 6 & & 0.587 & 1 \\
Legal & 0.494 & 5 & & 0.456 & 4 & & 0.504 & 5 \\
Commercial & 0.532 & 3 & & 0.508 & 1 & & 0.538 & 4 \\
Design and Procurement & 0.524 & 4 & & 0.467 & 3 & & 0.538 & 3 \\
Construction & 0.537 & 2 & & 0.486 & 2 & & 0.550 & 2 \\
Operation & 0.493 & 6 & & 0.449 & 5 & & 0.504 & 5 \\
\hline
\end{tabular}

Table 7. Ranking of the impacts $(I)$ of the six risk categories.

\begin{tabular}{|c|c|c|c|c|c|c|}
\hline \multirow[t]{2}{*}{ Risk categories } & \multicolumn{2}{|c|}{ Overall } & \multicolumn{2}{|c|}{ Public sector } & \multicolumn{2}{|c|}{ Private sector } \\
\hline & Mean & Rank & Mean & Rank & Mean & Rank \\
\hline Political & 0.664 & 1 & 0.586 & 4 & 0.684 & 1 \\
\hline Legal & 0.635 & 4 & 0.600 & 1 & 0.645 & 4 \\
\hline Commercial & 0.642 & 2 & 0.577 & 5 & 0.658 & 2 \\
\hline Design and Procurement & 0.636 & 3 & 0.595 & 3 & 0.647 & 3 \\
\hline Construction & 0.598 & 6 & 0.538 & 6 & 0.614 & 6 \\
\hline Operation & 0.616 & 5 & 0.597 & 2 & 0.620 & 5 \\
\hline
\end{tabular}

Based on the overall respondents' opinions (Table 5), 23 of 33 risk factors are considered critical (RL $\geq$ 0.8). However, the risk perceptions of the public and private sectors are quite different. Ten risks are 
considered critical by the public partner, whereas 22 risks are rated critical by the private partner. Interestingly, the respondents from the private sector generally rate a certain risk factor with a higher risk level $(R L)$ than the public sector does. This result shows that the private partner treats the PPP transportation projects in Vietnam riskier than the public partner does. It also confirms the result from a previous study on BOT/BT/BTO projects in Vietnam by Toan and Ozawa [7].

Considering the ranking of the probabilities $(P)$ of the risk categories (Table 6), both public and private sectors quite agree on the ranks of the construction $\left(2^{\text {nd }}\right)$, design and procurement $\left(3^{\text {rd }}\right)$, and operation $\left(5^{\text {th }}\right)$ risk categories. The public sector views that the commercial risk category is most likely to occur. The political risk category is the most likely risk category from the private sector's point of view, but it is the least likely from that of the public sector.

For the ranking of risk impact (I) (Table 7), the private sector suggests that the political and commercial risk categories have the most profound impact on their execution in PPP projects (first and second ranks, respectively). Meanwhile, the public sector disagrees with its counterpart as they put these two risk categories in the fourth and fifth ranks, respectively. This ranking clearly reflects the private sector's serious concerns about the country's political stability. This is because the nation's political stability and a transparent legal mechanism contribute to the investors' willingness to invest in PPP projects. In present, the public sector has realized the importance of stable legal regulation and framework on the success of PPP project execution in Vietnam. Clearly, inadequate legal and supervision systems, changes in laws and regulations, and changes in tax regulation have had adverse impacts on PPP projects for decades. Thus, they need to be amended immediately.

According to the overall respondents' risk perception presented in Table 5, there are five critical risk factors, the means of which are greater than 0.85 , namely land acquisition and compensation (Co2), delay in project approvals and permits (P2), inefficient feasibility study (D8), financial market risk (C1), and subjective project evaluation method (D3). These risk factors are considered the most critical risk factors for PPP transportation project in Vietnam that deserve to be investigated in detail as follows.

\subsubsection{Land acquisition and compensation (Co2)}

For both public and private sectors, this is the most critical risk factor with a probability of 0.718 , an impact of 0.767 (highest), and an RL of 0.924 (highest). In Vietnam, land acquisition and compensation have to face with various challenges. For example, the compensation for land acquisition proposed by the government agency is always lower than the market price. Other obstacles are different compensations for different provinces and corruption problems during the compensation process [19, 20]. Moreover, under the pilot PPP regulations [2], the Provincial People's Committees are responsible for site clearance, and the Authorized State is the entity party to the contract. This separation of roles and responsibilities often leads to delays in land clearance in practice if the coordination is inefficient [3]. Although the difficulties of land acquisition and compensation and their adverse impacts on PPP projects have been widely recognized, risks analysis and mitigation strategies were not well developed to cope with such problems [21]. The site clearance and compensation processes problems still continue. These problems could affect the entire schedule and viability of the PPP projects. Thus, the government must launch new appropriate policies to address these problems.

\subsubsection{Delay in project approvals and permits (P2)}

For most of the previous PPP projects, the Vietnamese government did not grant approvals on projectrelated issues as scheduled, and sometimes they even canceled what that had already been approved [19]. The prolonged approval process results from incompetence and unprofessionalism of government officials, complex approval procedures, as well as frequent laws and regulations changes, which cause difficulty in implementing PPP projects. Unfortunately, it is difficult to clearly allocate the approval and permit risk to the public or private sector [22]. As a result, delay in project approvals and permits is ranked as the second most critical risk factors for both partners. It also implies that the legal and regulations for PPP projects is seriously problematic in Vietnam. 


\subsubsection{Inadequate feasibility study (D8)}

In Vietnam, the proposal of a PPP transportation project must be assessed by the public sector first. If it is approved, the project will then be put into a PPP project list. Based on this list, an authorized state body will develop bidding documents and choose consultants to prepare feasibility study (FS) reports. A FS report contains such information as project risk analysis, and rights and obligations of the parties [3]. This information significantly contributes to the success of PPP transportation projects. According to our questionnaire surveys, the feasibility studies of PPP transportation projects in Vietnam are considered inadequate. This risk factor is in the third and seventh rank from the viewpoints of the private and public sectors, respectively. This probably contributes to the incapacity of FS consultants as well as different viewpoints and disputes between stakeholders [23]. Consequently, the FS reports require adjustments, or even changes, several times. To address this problem, the public and private sectors in Vietnam must focus on enhancing the quality of feasibility studies such as relying on qualified third-party consultants [24].

\subsubsection{Financial market (C1)}

The evaluation of financial viability is commonly used for assessing the potential of a PPP project to achieve the financial targets of its various stakeholders [25]. According to our survey, the financial market risk in Vietnam is highly critical (fourth rank for overall). It is one of the risk factors that repel private entities to invest in PPP transportation projects in Vietnam. In addition to this risk factor, fluctuation of interest rate (C2) and inflation (C4) led to a crisis in the Vietnamese construction industry. Unfortunately, these risk factors are considered macroeconomic conditions, which are impossible to avoid. The fluctuation of interest rate and inflation would cause the undesirable financial condition for all participants in the projects, especially their potential profits. Furthermore, the private sector's access to capital through loans from financial institutions will become much more difficult unless they get loan guarantees from the government.

\subsubsection{Subjective project evaluation method (D3)}

The PPP project evaluation encompasses such steps as determine a concession period, design a tariff structure, and forecast the market demand. Due to limited information, these evaluations are normally highly subjective. The risk level of subjective project evaluation method in PPP projects is in the fifth rank (overall). This result corresponds with those from previous studies (e.g., [11] and [23]). Most of the previous BOT/BT/BTO projects in Vietnam have been adversely affected by inappropriate concession periods and inaccurate market demand forecasts. For example, Phu My Bridge project (BOT) was the first cable-stayed bridge project in Ho Chi Minh City. After being operating for three years, the project was recently terminated by the concession company (Phu My Bridge Corporation, PMC) and was returned to the Vietnamese government. Several factors contribute to the failure of this project, including lack of supporting infrastructure (i.e., the public sector could not finish the eastern ring road to connect to the bridge), low traffic volume, low traffic revenue, all of which result from the inadequate valuation method for the project's financial feasibility. Thus, the efficacy of project assessment techniques is very important for the success of PPP transportation projects. The subjective evaluation methods must be carefully and reasonably applied.

\subsection{Risk Factors in PPP Projects among Selected Countries}

The top five critical risk factors (CRFs) for PPP transportation projects in Vietnam, which were identified in the previous section, are furthered examined by investigating their criticality on PPP projects in other countries. Herein, we review six important research works that were conducted after the 2008 economic crisis, as illustrated in Table 8. Even though these studies were not identical in terms of research objectives and methodologies, their results can be compared to appreciate the characteristics of major risks in other countries.

Based on our study, the land acquisition and compensation risk factor is the most critical risk PPP transportation projects in Vietnam. It mainly results from the inefficacy of legal policies and enforcement tools of the government. This result corresponds with those from India (4th rank) and Vietnam (2008 - $4^{\text {th }}$ rank). In Singapore, which is a developed country, site availability ( $35^{\text {th }}$ rank) is clearly not a dominant risk factor. Rather, lack of support from their government is viewed as the most critical risk factor that influences the performance of PPP projects in Singapore. 
The approvals and permits issue is considered one of the most critical risk factors in Vietnam (2 $2^{\text {nd }}$ rank in this study) and in India ( $5^{\text {th }}$ rank). As discussed in the previous section, the Vietnamese government did not grant approvals on project-related issues as scheduled, and sometimes they even cancelled what that had already been approved [19]. This is similar to the situation in India. In contrast, the approvals and permits

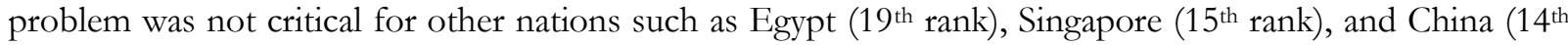
and $18^{\text {th }}$ rank).

The financial risk is dominant not only in Vietnam but also in other countries such as Egypt [foreign exchange ( $1^{\text {st }}$ rank) and inflation ( $3^{\text {rd }}$ rank)], Singapore [availability of finance $\left(2^{\text {nd }}\right.$ rank $)$ ], China [financial risk $\left(3^{\text {rd }}\right.$ rank $\left.)\right]$, India [delay in financial closure $\left(2^{\text {nd }}\right.$ rank $\left.)\right]$, and Vietnam [2008 - financial attraction (1 ${ }^{\text {st }}$ rank) and availability of finance ( $2^{\text {nd }}$ rank)]. In this study, the finance risk (4th rank) is specified as a risk that frequently occurs and has a severe impact. Thus, it often repels private businesses to participate in PPP projects in Vietnam.

Inadequate feasibility study and subjective project evaluation methods are two risk factors that are newly acknowledged in this study. These two problems are unique for Vietnam, not in the other countries. They essentially stem from lack of PPP's experience by the public sector and an immature legal basis for PPP implementation, which contribute to the efficacy of PPP project evaluation methods.

\subsection{Risk Perceptions of the Public and Private Sectors}

An empirical analysis is conducted to test the consensus among the two groups of respondents (i.e., the public and private sectors) on their ranking using the Spearman's rank correlation test. The relation between both groups' rankings is verified by a hypothesis testing at the 1\% significant level. It is found that the Spearman's correlation coefficients $\left(r_{s}\right)$ for ranking of the probabilities and impacts of the risk factors between the public and private sectors are 0.500 and 0.673 , respectively. Similarly, the Spearman's correlation coefficient for the combined risk levels between the public and private sectors is 0.711 . Table 9 summaries the Spearman's rank correlation coefficients $\left(r_{s}\right)$ and the significant levels (Sig.). It suggests that all the null hypotheses that have no significant correlation between the public sector and private sector can be rejected. It should be noted that the probability correlation between the public and private sectors is relatively medium with $r_{s}=0.5$, which indicates that the agreement on the rankings of probability is considerable [26].

The results from the Spearman's correlation test show that the public and private respondents share a relatively consistent view of the ranking of risk factors in PPP projects in Vietnam. The classification of critical risk levels also reveals some interesting results. As illustrated in Table 5, there are 22 critical risk factors (CRFs) (i.e., $R L \geq 0.8$ ) based on the perception of the private sector's respondents whereas there are only 10 $\mathrm{CRFs}$ that are recognized by the public sector's respondents. The private sector considers corruption (P3) and change of project scope (Co1) as the fourth and fifth ranks, respectively. Meanwhile, the public sector rates them as the $27^{\text {th }}$ and $22^{\text {nd }}$ ranks, respectively. Similar results are also found in lack of transparency in the bidding (D2) and inflation (C4). The results further unveil different perceptions of the public and private investors for the ranking of low capacity of concession company (D11) and demand issues (O5). Interestingly, the public sector suggests that corruption has no significant impact on the implementation of PPP projects, but the private sector expresses its serious concerns about this problem. Moreover, for the public sector, the capacity of the private sector and demand of projects are their critical concerns.

In order to clarify the different perceptions of both stakeholders on the criticality of PPP project risks in Vietnam, their perceptions are compared through independent sample $t$-test method (at $a=5 \%$ ). The null hypothesis is that there is no significant difference between the public and private sectors' perceptions. The results from a cross-comparison among the respondents are shown in Fig. 5. The factors with significant differences between the public and private sectors under an independent $t$-test are displayed in Table 10, pertaining to the risk factors of PPP implementation in Vietnam. 
Table 8. Comparison of CRFs among selected countries.

\begin{tabular}{|c|c|c|c|c|c|}
\hline \multirow[t]{2}{*}{ Country } & \multicolumn{5}{|c|}{ Rank of critical risk factors (CRFs) } \\
\hline & 1 & 2 & 3 & 4 & 5 \\
\hline $\begin{array}{l}\text { Vietnam } \\
\text { (this study) }\end{array}$ & $\begin{array}{l}\text { Land acquisition } \\
\text { and } \\
\text { compensation }\end{array}$ & $\begin{array}{l}\text { Delay in project } \\
\text { approvals and } \\
\text { permits }\end{array}$ & $\begin{array}{l}\text { Inadequate } \\
\text { feasibility study }\end{array}$ & Financial market & $\begin{array}{l}\text { Subjective } \\
\text { project } \\
\text { evaluation } \\
\text { methods }\end{array}$ \\
\hline $\begin{array}{c}\text { Egypt } \\
{[18]}\end{array}$ & $\begin{array}{l}\text { Foreign } \\
\text { exchange } \\
\text { fluctuation }\end{array}$ & Politics & Inflation & $\begin{array}{l}\text { Poor public } \\
\text { decision making } \\
\text { process }\end{array}$ & $\begin{array}{l}\text { Government } \\
\text { policy }\end{array}$ \\
\hline $\begin{array}{c}\text { Singapore } \\
{[12]}\end{array}$ & $\begin{array}{l}\text { Lack of support } \\
\text { from } \\
\text { government }\end{array}$ & $\begin{array}{l}\text { Availability of } \\
\text { finance }\end{array}$ & $\begin{array}{l}\text { Construction } \\
\text { time delay }\end{array}$ & $\begin{array}{l}\text { Inadequate } \\
\text { experience in } \\
\text { PPP }\end{array}$ & $\begin{array}{l}\text { Unstable } \\
\text { government }\end{array}$ \\
\hline $\begin{array}{l}\text { China } \\
{[11]}\end{array}$ & $\begin{array}{l}\text { Government's } \\
\text { intervention }\end{array}$ & $\begin{array}{l}\text { Poor political } \\
\text { decision making }\end{array}$ & Finance & $\begin{array}{l}\text { Government's } \\
\text { reliability }\end{array}$ & $\begin{array}{l}\text { Market demand } \\
\text { change }\end{array}$ \\
\hline $\begin{array}{c}\text { China } \\
{[10]}\end{array}$ & $\begin{array}{l}\text { Government } \\
\text { intervention }\end{array}$ & $\begin{array}{l}\text { Poor public } \\
\text { decision-making } \\
\text { process }\end{array}$ & $\begin{array}{l}\text { Government } \\
\text { corruption }\end{array}$ & Finance & $\begin{array}{l}\text { Inadequate law } \\
\text { and supervision } \\
\text { system }\end{array}$ \\
\hline $\begin{array}{c}\text { India } \\
{[9]}\end{array}$ & Pre-investment & $\begin{array}{l}\text { Delay in financial } \\
\text { closure }\end{array}$ & $\begin{array}{l}\text { Resettlement and } \\
\text { rehabilitation }\end{array}$ & $\begin{array}{l}\text { Delay in land } \\
\text { acquisition }\end{array}$ & Permit/approval \\
\hline $\begin{array}{c}\text { Vietnam } \\
{[7]}\end{array}$ & $\begin{array}{l}\text { Financial } \\
\text { attraction of } \\
\text { project investors }\end{array}$ & $\begin{array}{l}\text { Availability of } \\
\text { finance }\end{array}$ & Time and quality & $\begin{array}{l}\text { Land acquisition } \\
\text { and } \\
\text { compensation }\end{array}$ & $\begin{array}{l}\text { Unfair process of } \\
\text { selection of } \\
\text { private sector }\end{array}$ \\
\hline
\end{tabular}

Table 9. Spearman's rank correlation coefficient test between the public and private sectors.

\begin{tabular}{lllll}
\hline Comparison & & $\mathbf{r}_{\mathbf{s}}$ & Sig. & Conclusion \\
\hline Public sector ranking vs. & Probability & .500 & .010 & Reject $H_{o}$ at $1 \%$ sig. level and thus accept $H_{1}$ \\
\cline { 2 - 5 } Private sector ranking & Impact & .673 & .000 & Reject $H_{o}$ at $1 \%$ sig. level and thus accept $H_{1}$ \\
\cline { 2 - 5 } & Risk level & .711 & .000 & Reject $H_{o}$ at $1 \%$ sig. level and thus accept $H_{1}$ \\
\hline
\end{tabular}

$H_{o}=$ No significant correlation on the rankings of PPP risk factors between the two groups.

$H_{1}=$ Significant correlation on the rankings of PPP risk factors between the two groups.

Reject $H_{o}$ if the significant level ( $p$-value) is less than the allowance value of $5 \%$ (2-tailed).

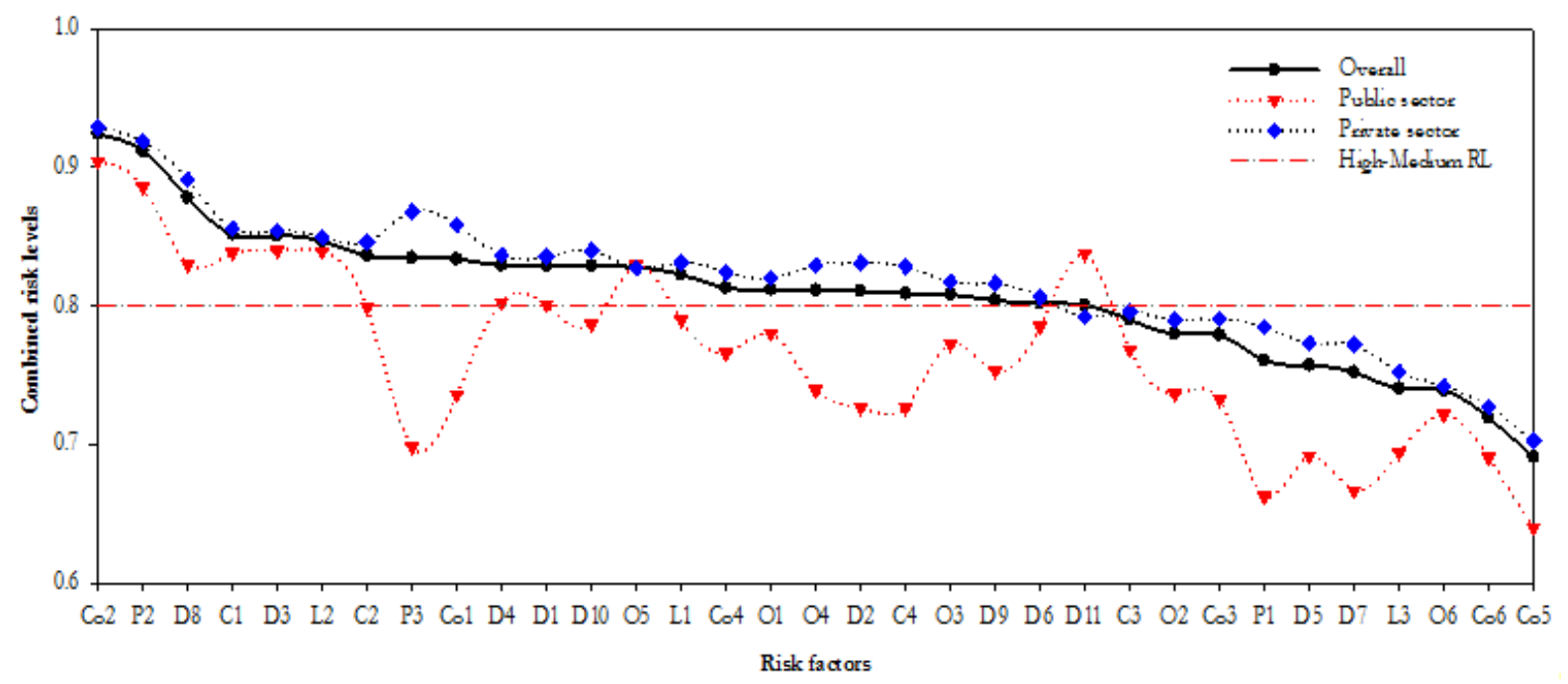

Fig. 5. Cross-comparison of CRFs among both groups of the respondents. 
Table 10. CRFs with significantly different risk perceptions of the public and private sectors under $t$-test.

\begin{tabular}{|c|c|c|c|c|c|c|c|c|c|}
\hline & \multirow[t]{2}{*}{ Risk factors } & \multicolumn{3}{|c|}{$\begin{array}{c}\text { Levene's test for equality of } \\
\text { variances }\end{array}$} & \multicolumn{5}{|c|}{ t-test for equality of means } \\
\hline & & Assumption & $\mathbf{F}$ & Sig. & t & df & $\begin{array}{c}\text { Sig. } \\
(2- \\
\text { tailed) }\end{array}$ & $\begin{array}{c}\text { Mean } \\
\text { Diff. } \\
(*)\end{array}$ & $\begin{array}{l}\text { Std. } \\
\text { Error } \\
\text { Diff. }\end{array}$ \\
\hline \multicolumn{10}{|c|}{ Private sector vs. Public sector } \\
\hline P3 & Corruption & $\begin{array}{l}\text { Equal variances } \\
\text { not assumed }\end{array}$ & 14.580 & .000 & 4.875 & 28.32 & 0.000 & 0.164 & 0.034 \\
\hline Co1 & $\begin{array}{l}\text { Change of project } \\
\text { scope }\end{array}$ & $\begin{array}{l}\text { Equal variances } \\
\text { not assumed }\end{array}$ & 7.430 & .007 & 4.267 & 29.49 & 0.000 & 0.122 & 0.029 \\
\hline D2 & $\begin{array}{l}\text { Lack of transparency } \\
\text { in bidding }\end{array}$ & $\begin{array}{l}\text { Equal variances } \\
\text { assumed }\end{array}$ & 1.686 & .197 & 3.515 & 121 & 0.001 & 0.099 & 0.028 \\
\hline $\mathrm{C} 4$ & Inflation & $\begin{array}{l}\text { Equal variances } \\
\text { assumed }\end{array}$ & 1.730 & .191 & 4.260 & 121 & 0.000 & 0.097 & 0.023 \\
\hline O4 & Payment issues & $\begin{array}{l}\text { Equal variances } \\
\text { assumed }\end{array}$ & 3.431 & .066 & 3.888 & 121 & 0.000 & 0.090 & 0.023 \\
\hline D8 & $\begin{array}{l}\text { Inadequate feasibility } \\
\text { study }\end{array}$ & $\begin{array}{l}\text { Equal variances } \\
\text { assumed }\end{array}$ & .003 & .957 & 2.948 & 121 & 0.004 & 0.064 & 0.022 \\
\hline D10 & $\begin{array}{l}\text { Inappropriate } \\
\text { allocation of } \\
\text { responsibility and risk }\end{array}$ & $\begin{array}{l}\text { Equal variances } \\
\text { assumed }\end{array}$ & .168 & .682 & 3.028 & 121 & 0.003 & 0.055 & 0.018 \\
\hline C2 & $\begin{array}{l}\text { Interest rate } \\
\text { fluctuations }\end{array}$ & $\begin{array}{l}\text { Equal variances } \\
\text { assumed }\end{array}$ & 1.550 & .216 & 2.280 & 121 & 0.024 & 0.047 & 0.021 \\
\hline
\end{tabular}

The public and private sectors are "diverse actors," which are contractually bound to deliver "mutually agreed objectives" [27]. The survey data reveal that about one-third of the CRFs (8 out of 23 factors) show significantly different risk perceptions between the public and private participants, as shown in Table 10. Although the rankings of combined risk levels are different between the public and private sectors, both sectors agree that the land acquisition and compensation (Co2) and project approvals and permits (P2) issues are most critical for PPP implementation. The risk factors with greatest mean differences (MDs) between the private and public sectors are corruption $(\mathrm{P} 3)(\mathrm{MD}=0.164)$, change of project scope $(\mathrm{Co} 1)(\mathrm{MD}=0.122)$, and lack of transparency in bidding $(\mathrm{D} 2)(\mathrm{MD}=0.099)$. The results also indicate that several risk factors entail significant differences in the perceptions of public and private entities such as corruption (P3), change of project scope (Co1), lack of transparency in bidding (D2), inflation (C4), payment risk (O4), inadequate feasibility study (D8), inappropriate allocation of responsibility and risk (D10), and fluctuation of interest rate (C2). These differences result from the fact that the public and private sectors are independent entities with different viewpoints and perspectives about risk factors [28]. For example, the private sector usually more focuses on the risk factors related to the feasibility stage of PPP projects such as feasibility study, project scope, bidding transparency, risk allocation, and corruption. Moreover, the private sector also concerns about some factors related to commerce and payment such as inflation, interest rate fluctuation, and payment. In contrast, the public sector is more concerned about the capacity of the private sector in PPP projects.

Eight CRFs that indicate different risk perceptions between the public and private sectors are categorized into three main groups: (1) issues related to the tendering process, (2) issues related to commercial problems, and (3) issues related to payment problems. Their details are as follows.

\subsubsection{Issues related to the tendering process}

This group concerns lack of transparency in bidding (D2), corruption (P3), inadequate feasibility study (D8), change of project scope (Co1), and inappropriate allocation of responsibility and risk (D10). These issues are clearly caused by various activities of stakeholders and non-transparency throughout the tendering process of PPP projects. Normally, open competitive bidding is widely required in the PPP regulations of Vietnam. It is supposed to enhance the transparency of the investment environment, which will attract more potential investors. However, lack of transparency in the tendering process is still a very common complaint by the private sector $[29,30]$. In Vietnam, since inequity and fraud in the tendering process is a very common problem [20], PPP contracts are often awarded to incapable investors. Moreover, the absence of transparent procurement 
processes can readily result in substantial corruption [31]. The anti-corruption legal framework in Vietnam is considered one of the best legal frameworks in Asia. Yet, its implementation is facing such problems as lack of transparency, accountability, low payment for government officials, and inadequate system for holding officials accountable for their actions. In this research, corruption may cause a significant loss for the private sector (4th rank), whereas it is considered less severe by the public sector (27 th rank) in PPP transportation projects in Vietnam.

It is widely accepted that the feasibility study assessment is extremely crucial for PPP transportation projects. For the public sector in Vietnam, competent state agencies organize bidding under regulations and select professional consultants to assess the feasibility of PPP projects [2]. For the private sector, assessing the viability of PPP projects significant influences their decisions to invest [32]. The private sector then defines risk sharing scenarios under which the project becomes viable, incorporates risks into cash-flow analysis, and defines suitable risk mitigation strategies. However, the feasibility study of PPP projects in Vietnam is experiencing several challenges such as instable politics, the public sector having limited experience, undefined public contribution of funds, unrealistic forecast on future economic development and demand, low actual traffic revenues [19], as well as immature legal basis [3]. An example for misjudging the feasibility study that led to the failure of PPP projects in Vietnam is the Phu My Bridge project. Due to the delay of the East ring road, the actual number of traffic was lower than the forecast one. As a result, the revenue was not enough to pay the concessionaire's annual debt. Moreover, some of competing alternative projects were approved by the Vietnamese government during the implementation of the Phu My project. Finally, the concession company of Phu My Bridge decided to terminate the concession and returned the project to the government.

The complexity of contractual relations among stakeholders and a long concession period distinguish PPP projects from traditional transportation projects. They also significantly contribute to a large number of uncertainties and risks associated with the PPP projects [33]. Since the risk allocation frameworks in PPP contracts are often complicated and unclear, both public and private partners are susceptible to conflicts and disputes during the execution of contracts. Moreover, as discussed earlier, there are differences between the public and private sectors' risk perceptions in PPP projects. The public sector often transfers most of the risks to the private partner, whereas the private sector is willing to take such risks, but with more incentives from the government. However, in Vietnam most of the risks are usually allocated to the private sector without guarantees from the government. To address these problems, standardized bidding documents and contracts should be prudently prepared by the government, which might be supported by capable professional consultants to attract the participation of private investors in PPP transportation projects in Vietnam.

\subsubsection{Issues-related to commercial problems}

This group concerns fluctuation of interest rate (C2) and inflation (C4). These issues are clearly caused by instable commercial factors in Vietnam. Indeed, fluctuation of interest rate and inflation led to the 2008 and 2011 crises in the Vietnamese construction industry. The instability of interest rate and inflation contribute to the undesirable financial conditions of all stakeholders in PPP projects, especially their potential profit. Typically, both risks should be shared by both public and private sectors because a single party cannot deal with them alone $[12,34]$. Thus, the Vietnamese government should attain appropriate policies to respond to these risk factors together with private investors, including risk sharing, minimum revenue guarantees, and compensation clauses in PPP contract.

\subsubsection{Issues-related to payment issues}

For typical PPP projects, the private sector will not earn any incomes until the operation phase. The payment risk occurs when the government or consumers (users) are not able to or are willing to pay due to social or other reasons. Thus, the unavailability of financial instruments, which leads to difficulty in financing, would cause project termination and loss of funds invested [12]. Besides, delays in the disbursement of the public sector can also lead to difficulties for private investors and PPP projects. Moreover, risks related to an unrealistic forecast on future demand and low actual traffic revenues could also cause payment problems [19]. The Yen Lenh Bridge project is a failure example of low actual traffic revenues, which affected the payment of BOT projects in Vietnam. Indeed, after Yen Lenh Bridge was completed, actual traffic revenues were lower than estimated, one year after the opening the toll fees were not enough to pay interest on the 
concessionaire's bank loans [19]. It means that the investment capitals cannot be returned during the operation stage. In order to address this problem, the Ministry of Finance reported to the government to switch the PPP scheme from BOT (Build-Operate-Transfer) to BT (Build-Transfer) form. As the result, Yen Lenh Bridge was transferred to Vietnamese government since then.

\subsection{Conclusion}

PPP has been proclaimed as a new scheme for infrastructure development in Vietnam. The 2015 PPP regulations along with pilot PPP projects are expected to enhance the opportunity for foreign and domestic investors to enter into this new market. In this paper, we examine the critical risk factors and the different perceptions among stakeholders related to PPP transportation projects in Vietnam. The important results are: (1) there are a large number of critical risk factors affecting PPP transportation projects, (2) the private sector treats the PPP transportation projects as riskier than the public sector does, and (3) the different risk perceptions between the public and private participants can be observed in the three major concern issues.

About two-thirds of the risk factors (23 of 33 risks) are regarded as highly critical by both public and private sectors. Interestingly, the respondents from the private sector generally rate a certain risk factor with a higher risk level (RL) than the public sector does. The five most critical risk factors are: (1) Land acquisition and compensation, (2) Delay in project approvals and permits, (3) Inadequate feasibility study, (4) Financial market, and (5) Subjective project evaluation method. Clearly, most of them are related to the feasibility study stage of PPP projects. This is why the PPP transportation projects in Vietnam must be encountering various difficulties in attracting the private sector.

Per our statistical analysis, significant differences in the perceptions of public and private entities are observed for eight critical risk factors (CRFs), which are categorized into three main groups: (1) tendering process (i.e., lack of transparency in bidding, corruption, inadequate feasibility study, change of project scope, and inappropriate allocation of responsibility and risk), (2) commercial problems (i.e., fluctuation of interest rate, and inflation), and (3) payment issues.

These results would benefit the Vietnamese government to understand the perceptions and expectations of private investors. It is necessary for the government to revise their policies accordingly so that PPP transportation projects will become more attractive for the private sector. The important recommendations obtained from our study can be summarized as follows.

- The legal framework for PPP projects should be established appropriately.

- The government should provide good coordinating and supporting bodies for PPP projects.

- The government should make a strong commitment to ensure competition and transparency during the bidding process.

- The anti-corruption legal framework should be enforced closely to reduce the likelihood of corruption.

- The government needs to make a rational long-term policy to restrict the changes in size or scope of PPP projects.

- The feasibility studies of PPP projects must be carefully evaluated by the third-party consultant. In addition, the government should also pay attention to project proposals from the private sector.

- A risk should be allocated to the party that has the best capacity and is willing to manage it. The government also needs an appropriate policy for sharing some critical risks with the private sector.

The stakeholders' risk allocation for such critical risk factors in Vietnam's PPP transportation projects should be analyzed in future research works. Moreover, the risk mitigation strategies of the public and private sectors should be also identified and analyzed. These results would benefit the government and private investors in the negotiation or feasibility stage, which a critical stage of PPP transportation projects, by reducing time and cost for negotiation.

\section{References}

[1] Decree No.108/2009/ND-CP on Investment in the Form of Build-Operate-Transfer, Build-Transfer-Operate or Build-Transfer Contract, 2009.

[2] Decision No.71/2010/QD-TTg of the Prime Minister Dated November 9, 2010 Promulgating the Regulations on Pilot Investment in the Public-Private Partnership Form, 2010. 
[3] Ashurst. (2012). A Star in the Ascendant? PPP Opportunities in Vietnam [Ashurst insight: Infrastructure Opportunities] [Online]. Available: https://www.ashurst.com/doc.aspx?id_Content $=6542$

[4] Decree No.15/2015/ND-CP on PPP Investment Form Dated Feb 14, 2015, 2015.

[5] T. Merna and N. J. Smith, Guide to the Preparation and Evaluation of Build-Own-Operate-Transfer (BOOT) Project Tenders. Asia Law \& Practice Limited, 1996.

[6] V. Ongipattanakul, Bangkok Expressway: Imminent Debt Restructuring Success. Emerging Markets Equity Research. Bangkok: Bloomberg, 1999.

[7] N. T. Toan and K. Ozawa, "Stakeholders' perception on risks of BOT infrastructure projects in Vietnam," presented at CIB W107 Construction in Developing Countries International Symposium, Trinidad \& Tobago, Jan. 16-18, 2008.

[8] A. V. Thomas, S. N. Kalidindi, and K. Ananthanarayanan, "Risk perception analysis of BOT road project participants in India," Construction Management and Economics, vol. 21, no. 4, pp. 393-407, 2003.

[9] K. Iyer and M. Sagheer, "Hierarchical structuring of PPP risks using interpretative structural modeling," Journal of Construction Engineering and Management, vol. 136, no. 2, pp. 151-159, 2010.

[10] Y. Xu, J. F. Y. Yeung, A. P. C. Chan, D. W. M. Chan, S. Q. Wang, and Y. Ke, "Developing a risk assessment model for PPP projects in China-A fuzzy synthetic evaluation approach," Automation in Construction, vol. 19, pp. 929-943, 2010.

[11] Y. Ke, S. Wang, A. P. C. Chan, and E. Cheung, "Understanding the risks in China's PPP projects: Ranking of their probability and consequence," Engineering, Construction and Architectural Management, vol. 18, no. 5, pp. 481-496, 2011.

[12] B. G. Hwang, X. Zhao, and M. J. S Gay, "Public private partnership projects in Singapore: Factors, critical risks and preferred risk allocation from the perspective of contractors," International Journal of Project Management, vol. 31, pp. 424-433, 2013.

[13] D. Cooper, G. Stephen, R. Geoffrey, and W. Phil, Managing Risk in Large Projects and Complex Procurements. England: John Wiley \& Sons, 2004.

[14] S. T. Do, "Risk management for international construction joint ventures—Case studies of Vietnamese contractors," Master's thesis, Chulalongkorn University, Bangkok, Thailand, 2011.

[15] A. Dias and P. G. Ioannou, "Company and project evaluation model for privately promoted infrastructure projects," Journal of Construction Engineering and Management, vol. 122, no. 1, pp. 71-82, 1996.

[16] A. Ng and M. Loosemore, "Risk allocation in the private provision of public infrastructure," International Journal of Project Management, vol. 25, no. 1, pp. 66-76, 2007.

[17] A. Karim and N. Alkaf, "Risk allocation in public private partnership (PPP) project: A review on risk factors," International Journal of Sustainable Construction Engineering and Technology, vol. 2, no. 2, pp. 8-16, 2011.

[18] A. S. Ezeldin and Y. Badran, "Risk decision support system for public private partnership projects in Egypt," International Journal of Engineering and Innovative Technology, vol. 3, no. 2, pp. 479-486, 2013.

[19] S. Ogunlana and M. P. Abednego, "Case study II - Governance issues in the Yen Lenh bridge BOT project," in Public-Private Partnership in Infrastructure Development: Case Studies from Asia and Europe, H. W. Alfen, Ed. Weimar, Germany: Bauhaus-Universität Weimar, 2009, pp. 63-88.

[20] N. D. Long, S. Ogunlana, T. Quang, and K. C. Lam, "Large construction projects in developing countries: A case study from Vietnam," International Journal of Project Management, vol. 22, no. 7, pp. 553 $561,2004$.

[21] World Bank, Infrastructure Strategy - Cross-Sectoral Issues, 2006.

[22] B. Li, A. Akintoye, P. Edwards, and C. Hardcastle, "The allocation of risk in PPP/PFI construction projects in the UK," International Journal of Project Management, vol. 23, pp. 25-35, 2005.

[23] M. Kert, A. B. Izaguirre, and K. Ada, Revival of Private Participation in Developing Country Infrastructure. Gridlines; No. 16. Washington, DC: World Bank, 2007. [Online]. Available: http://documents.worldbank.org/curated/en/771931468314374532/Revival-of-private-participationin-developing-country-infrastructure

[24] J. Valentine, PPP in Infrastructure - Best Practices from International Experience and Applications for Thailand, 2008.

[25] A. Pantelias and Z. Zhang, "Methodological framework for evaluation of financial viability of publicprivate partnerships: Investment risk approach," Journal of Infrastructure Systems, vol. 16, no. 4, pp. 241 250, 2010.

[26] J. Cohen, Statistical Power Analysis for the Behavioral Sciences, 2nd ed. Hillsdale, NJ: Lawrence Erlbaum Associates, 1988. 
[27] A. Roumboutsos and N. Chiara, Public Private Partnerships: A Strategic Partnering Approach, Revamping PPPs' Symposium - From 'Revisiting and Retbinking' to 'Revamping and Revitalizing'PPPs. Hong Kong: The University of Hong Kong, 28 February 2009.

[28] S. O. Babatunde, A. Opawole, and O. E. Akinsiku, "Critical success factors in public-private partnership (PPP) on infrastructure delivery in Nigeria," Journal of Facilities Management, vol. 10, no. 3, pp. 212-225, 2012.

[29] J. Ward and J. Sussman. (2005). Analysis of the Malaysian Toll Road Public-Private Partnership Program and Recommendations for Policy Improvements [Online]. Available: http://esd.mit.edu/staging/WPS/esd-wp2005-09.pdf

[30] V. Cuttaree, Key Success Factors for PPP Projects based on International Experience. St. Petersburg: World Bank, Europe \& Central Asia Region, 2008.

[31] ADB, Developing Best Practices for Promoting Private Sector Investment in Infrastructure: Airports and Air Traffic Control. Asian Development Bank, 2000.

[32] I. D. Ozdoganm and M. T. Birgonul, "A decision support framework for project sponsors in the planning stage of build-operate-transfer (BOT) projects," Construction Management and Economics, vol. 18, no. 3, pp. 343-353, 2000.

[33] Y. H. Kwak, Y. Chih, and C. W. Ibbs, "Towards a comprehensive understanding of public private partnerships for infrastructure development," California Management Review, vol. 51, pp. 51-78, 2009.

[34] Y. Ke, S. Wang, A. P. C. Chan, and P. T. I. Lam, "Preferred risk allocation in China's public-private partnership (PPP) projects," International Journal of Project Management, vol. 28, no. 5, pp. 482-492, 2010. 